\title{
A PREDICTION FOR TEACHER COMMITMENT: EFFECTS OF MANAGERIAL STYLE, BURNOUT AND DEMOGRAPHICS ${ }^{1}$
}

\author{
Gökhan DEMIRHAN \\ Uşak University \\ Cemil YÜCEL \\ Osmangazi University \\ cemilyucel@gmail.com
}

\begin{abstract}
The purpose of this study is to determine the effects of managerial style, teacher burnout and demographics on teacher commitment. In accordance with this aim, a quantitative casual research design was implemented. Data of the research were gathered from 280 primary school teacher, by a questionnaire including managerial style, teacher burnout, teacher commitment and teacher demographics forms. For each research questions, Hierarchical Linear Regression analysis was carried out. According to the findings, task oriented behaviors of principal, emotional exhaustion level of the teacher, self-inadequacy feelings of teacher, marital status and work time spending at the same school predicts teacher commitment significantly. On the other hand, human orientation, isolation level from work environment, physical burnout level, vocational burnout level, gender, professional experience, educational level and working status variables does not predicts teacher commitment.
\end{abstract}

Keywords: Teacher commitment, teacher burnout, managerial style, teacher demographics.

\section{Introduction}

Effectiveness is the most common and fundamental area of interest for educational systems worldwide. Miller (1981) highlights that leadership behaviors and staff morale is geared to effectiveness of school. After nearly 30 years, PISA 2009 report entitled "What Makes a School Successful” includes a chapter named Learning Environment, emphasizing importance of leadership, school climate and emotional picture of staff on school effectiveness (OECD, 2010, 87-101). In the meantime, educational administration researchers' intensely interested in interaction between leader attitudes and emotional characteristics of staff. These studies cumulatively gathered descriptive, relational, experimental and casual findings about this interaction. Surely, interaction between managerial attitudes and staff characteristics will be in focus for long years, because student

\footnotetext{
${ }^{1}$ The data used in this study was taken from the master thesis of the author, titled "The Relationship Between Managerial Styles of Educational Administrators and Burnout and Commitment Levels of Teachers"
} 
characteristics, expectations from education, manager profiles, teacher adequacies, working conditions, social structure and anything in the world is changing and this change is everlasting. This study is focused on interaction between teacher commitment and managerial style of the principal, organizational burnout level of teacher and some demographics.

\section{Managerial Style}

Ohio State University Leadership Studies offered two dimensioned managerial style: initiating structure and consideration after 1945. Closely, University of Michigan studies determined these two dimensions of leadership: production centered and employee centered (Warrick, 1981). In the years followed, theories like Blake and Mouton's Managerial Grid Theory (1964), Reddin's 3D Leadership Model (1970), Hersey and Blanchard's Situational Leadership Model (1988) used this two-dimensioned behavioral framework. In this study these dimensions like task orientation and human orientation was used. Task orientation includes principal's behaviors and attitudes on organizational aims, defining individual and group roles to guarantee absolute production/service process, success and outcome in concordance with instructions and guidelines. Nonetheless, Human orientation of principal is based on democratic, supportive, emphasizing on subordinate needs and motivation, delegated power/authority and establishing an amicable work atmosphere (Bass, 1985; Fiedler, 1967; Northouse, 2004; Stodgill, 1974).

\section{Burnout}

Freudenberger (1974) defines burnout as unsuccessfulness, attrition and dissipation. Another definition describes burnout as occupational stress in human service professionals, which results from the demanding and emotionally charged relationships between caregivers and recipients (Maslach \& Jackson (1984).With another approach, Cherniss (1980) maintains that burnout is a result of unsuccessful attempts to deal with stress emanated from job and social life. Maslach and Jackson argued organizational burnout via three dimension; 
emotional exhaustion, depersonalization, and lack of personal accomplishment. In this study teacher burnout has five-dimensioned structure, including emotional exhaustion, inadequacy feelings, isolation in work place, physical burnout and loosing enthusiasm for profession.

\section{Commitment}

Modway, Steers and Porter (1979) states that the organizational commitment denotes cohesion and identification level to an organization of an individual. Meyer and Allen (1991) define organizational commitment via three dimensions; affective, continuance and normative commitment. Affective commitment means emotional attachment and satisfaction of members to/from the organization in general. Normative commitment represents individual's feelings of beholden. Continuance commitment is member's desires to being a part of organization. Allen and Meyer (1990) maintains that all these three sub factors of commitment can be characterized via member's wish of staying in organization and summaries these three factors as; affectively committed members, says that he/she wants to stay in organization, normatively committed member thinks that staying in organization is a moral necessity and continuance commitment gives impression such as 'being a part of this organization is good for me' to the members. At this study, affective and normative commitment items of survey were conjoined on factor analysis and this dimension of commitment named as normative commitment.

\section{Purpose and Research Questions}

The purpose of this research is to define the effects of managerial style, teacher burnout and demographics on teacher commitment. In conformity to the purpose, these questions would be pertinent; a. What are the prediction levels of managerial style of the principal, teacher burnout and demographics on teachers' general commitment level? $\mathrm{b}$. What are the prediction levels of managerial style of the principal, teacher burnout and demographics on teachers' normative commitment level?; c. What are the prediction levels of 
managerial style of the principal, teacher burnout and demographics on teachers' continuance commitment level?

\section{Method}

\section{Design}

This study has a casual research model. Casual research design is generally used when the researcher thinks that there is a causal connection between the variables (Ellett \& Ericson, 1983). Hypothesis of this research is structured on the idea of underlying cause - effect relation between teacher commitment and managerial style of the principal, teacher burnout and some demographics such as gender, marital status, professional experience, work time spent at the same school, educational level and working status.

\section{Sample}

The Sample of this study is 280 primary school teachers selected randomly from 1001 teacher working at Uşak (Western Anatolia) city center in 2009-2010 academic years, via stratified sampling method. Confidence internal ratio of the sample is $4.97 \%$ for $95 \%$ confidence level for this population. $53.9 \%$ of the sample is male $(\mathrm{N}: 151)$ and $46.1 \%$ is female (N: 129).

\section{Instruments}

\section{Measuring Managerial Style}

In the literature review, there are a lot of scales and measures for assessment of managerial style. Surely best known is Leadership Behavior Description Questionnaire. LBDQ and alike' s mostly depends on Ohio State and Michigan Universities' leadership studies (1945), which focused on two dimensions of administrative activities: consideration and initiating structure (Newstrom \& Davis, 1993, 228). Almost five decades, researchers used two main tendencies: job or task orientation and human or relation orientation in leadership style measurement studies. In this study, two-dimensioned survey was used 
including 42 items about daily managerial activities of a principal. Survey is based on a Likert-type scale between 1-9 points about attitudes of principals for each item on two dimensions; task and human orientation. Cronbach's Alpha internal consistency coefficients is (.97) for Task Orientation dimension and (.98) for Human Orientation.

\section{Measuring Burnout}

For assessment of teacher burnout, 32 items were used in this survey. Survey was developed by Özdemir (2008) and Yücel for a master thesis on teacher burnout. According to Özdemir, the survey has 5 dimensioned factor structures and Cronbach's Alpha internal consistency coefficient was calculated (.94).

For this study after removing 5 items according to the reliability analysis, due to the item-total correlation coefficient problems, the current survey declined to 27 items. According to factor analysis (Principal Component Analysis, Varimax rotation with Kaiser Normalization) results, the 27 items were categorized into 5 dimensions. Reliability and structure validity statistics of burnout survey is given at Table 1 .

Table1

\begin{tabular}{|c|c|c|c|c|}
\hline Dimensions & $\begin{array}{l}\text { Numb } \\
\text { er of } \\
\text { Items }\end{array}$ & $\alpha$ & $\begin{array}{l}\% \\
\text { Variance } \\
\text { Explained }\end{array}$ & $\begin{array}{l}\text { Initial } \\
\text { Eigenvalues }\end{array}$ \\
\hline $\begin{array}{l}\text { Emotional } \\
\text { Burnout }\end{array}$ & 8 & .88 & 15,350 & 9,793 \\
\hline $\begin{array}{l}\text { Feeling } \\
\text { Inadequate }\end{array}$ & 5 & .85 & 13,203 & 2,590 \\
\hline Isolation & 5 & .85 & 12,662 & 1,715 \\
\hline Physical Burnout & 5 & .85 & 12,471 & 1,393 \\
\hline $\begin{array}{l}\text { Vocational } \\
\text { Burnout }\end{array}$ & 4 & .72 & 8,350 & 1,260 \\
\hline Total & 27 & .93 & 62,036 & \\
\hline
\end{tabular}

\section{Measuring Commitment}


For assessment of teacher commitment, 12 items were used in this survey. Survey was developed by Yıldırım (2009) and his advisor Yücel for a master thesis about teacher burnout. According to Y1ldirım, the survey has 3 dimensioned factor structures and Cronbach's Alpha internal consistency coefficient was calculated (.93).

As a result of factor analysis carried out through this study, 12 items includes two dimensions named normative commitment and continuance commitment. Reliability and structure validity statistics of teacher commitment survey is given at Table 2 .

Table2

\begin{tabular}{lccll} 
Reliability and Validity & Statistics of Teacher Commitment Survey \\
\hline Dimensions & $\begin{array}{l}\text { Number } \\
\text { of } \\
\text { Items }\end{array}$ & $\alpha$ & $\begin{array}{l}\% \text { Variance } \\
\text { Explained }\end{array}$ & $\begin{array}{l}\text { Initial } \\
\text { Eigenvalues }\end{array}$ \\
$\begin{array}{l}\text { Normative } \\
\text { Commitment }\end{array}$ & 8 & .93 & 41,183 & 6,931 \\
$\begin{array}{l}\text { Continuance } \\
\text { Commitment } \\
\text { Total }\end{array}$ & 4 & .79 & 25,392 & 1,058 \\
\hline KMO-MSA; .934, Barlett's TS $\chi^{2}: 2308,764$, df: $\left.66, \mathrm{p}:, 000\right)$ &
\end{tabular}

\section{Demographics}

Through this research a form was given to teachers including gender, marital status, professional experience, working time during the school, educational level and working status variables in addition to other instruments. Gender and marital status variables were coded as nominal variables. Professional experience, working time during school, educational level and working status variables were coded as scale type variables. Detailed information is given at the Findings section to guarantee intelligibility of analysis carried out.

\section{Data Analysis}

In this quantitative casual research model study, hierarchical linear regression analysis (Hierarchical Regression Model: HRM) was carried out for data analysis on each research questions. In addition, Pearson Correlation analysis is used for checking multicollinearity 
problems on sub factors of the variables entered to the regression model. Correlations between sub factors should be under .70 to avoid multicolinearity (Nunnaly, 1978). According to the findings of correlation analysis, none of the correlation coefficients between sub factors of the burnout scale is over .70. However, the correlation between task orientation and human orientation sub factors of managerial style scale is over .70 in this study. It is to be thought of bureaucratic and highly regulative structure of the educational management system of Turkey causes misperception about dualist structure (task and human) of the principals' managerial preferences. Correlation matrix and descriptive statistics are given below (Table 3).

Table 3

Correlation Martix and Descriptive Statistics of Variables Used in Hierarchical Regression Model

$\begin{array}{lllllllll}\bar{X} & \text { sd. } & 1 & 2 & 3 & 4 & 5 & 6 & 7\end{array}$

General Commitment Level 3,14 1,424

Normative Commitment $\quad 1,546$

Level 3,36

Continuance Commitment $\quad 1,460$

Level 2,72

1. Emotional Burnout Level $1,93 \quad 0,726 \quad 1$

2. Level of Feeling $\quad 1,720,743,613^{* *} 1$

Inadequate

3. Isolation $\quad 1,670,686,472^{* *}, 511^{* *} 1$

4. Physical Burnout Level 2,45 0,749,605 $376^{* * *}, 298^{* * *} 1$

5. Vocational Burnout Level 1,85 $0,841,498^{* *}, 496^{* *}, 429^{* *}, 305^{* *} 1$

6. Task Orientation $\quad 6,741,665-, 180^{* *}-, 196^{* * *}-, 230^{* *}-, 119^{*}-, 212^{* *} 1$

7. Human Orientation $\quad 6,77 \quad 1,666-, 136^{*}-, 173^{* *}-, 209^{* *}-, 089-, 213^{* *}, 831^{* *} 1$ **. $\mathrm{p}<.01, * . \mathrm{p}<.05, \mathrm{~N}: 280$

In the regression model, three blocks were used. Variables of the first block are Task Orientation and Human Orientation levels of the school administrators'. In the second block, five sub factors of teacher burnout scale; Emotional Burnout Levels, Levels of Feeling Inadequate, Isolation Levels from Work Environment, Physical Burnout Levels and Vocational Burnout Levels of teachers' variables were used. Third block includes demographic variables about teachers such as gender, marital status, professional experience, working time during the school, educational level and working status. Variables in first and 
second blocks are coded as scale type variables. Possible scores of the Task and Human Orientation scale can be in the 1-9 range, Burnout scale can be in 1-5 range and commitment scale can be in 1-7 range. Professional experience and working time variables were coded as free of range scale type through year.

\section{Findings}

\section{Prediction on General Commitment Levels of Teachers}

Table4

Hierarchical Regression Model for General Commitment Levels of Teachers.

Std. ErrorChange Statistics

$$
\text { of the } \mathrm{R}^{2} \quad \text { Sig. F Change }
$$

$\mathrm{R} \quad \mathrm{R}^{2} \quad$ Adjusted $\mathrm{R}^{2}$ Estimate Change $\mathrm{F}$ Change df1 df2 (p)

$\begin{array}{lllllllll}, 313^{\mathrm{a}} & , 098 & , 092 & 1,35835 & , 098 & 15,064 & 2 & 277 & , 000 \\ & & & & & & & & \\ , 402^{\mathrm{b}} & , 162 & , 140 & 1,32143 & , 064 & 4,139 & 5 & 272 & , 001 \\ & & & & & & & \\ , 477^{\mathrm{c}} & , 228 & , 190 & 1,28273 & , 066 & 3,776 & 6 & 266 & , 001\end{array}$

a. Predictors: (Constant) Task Orientation, Human Orientation

b. Predictors: (Constant) Task Orientation, Human Orientation, Emotional Burnout, Feeling Inadequate, Isolation, Physical Burnout, Vocational Burnout

c. Predictors: (Constant) Task Orientation, Human Orientation, Emotional Burnout, Feeling Inadequate, Isolation, Physical Burnout, Vocational Burnout, Gender, Marital Status, Professional Experience, Work Time Spent at the Same School, Educational Level, Working Status

According to the findings from HRM (Table 4), managerial style of the principal, teacher burnout and demographics explains $22.8 \%$ of variance on general teacher commitment. Variables in the first block, task orientation and human orientation explains 9,8\% of the Total variance (R: .313, R2: .098, p: .000). When the second block added on, including emotional burnout level, level of feeling inadequate, isolation level from work environment, physical burnout level and vocational burnout level of the teachers, the model explains $16,2 \%$ of the variance on total and the level of prediction change is statistically significant (R: .402, R2: .162, p: .001). The effect of the second block on explained variance 
is $6.4 \%$. At the last model, the single effect of variables in the third block, gender, marital status, professional experience, working time, educational level, working status, is $6.6 \%$ on prediction of teacher commitment level and this effect changes explained variance significantly (R: .477, R2: .228, p: .001).

Table 5

Coefficients ${ }^{*}$

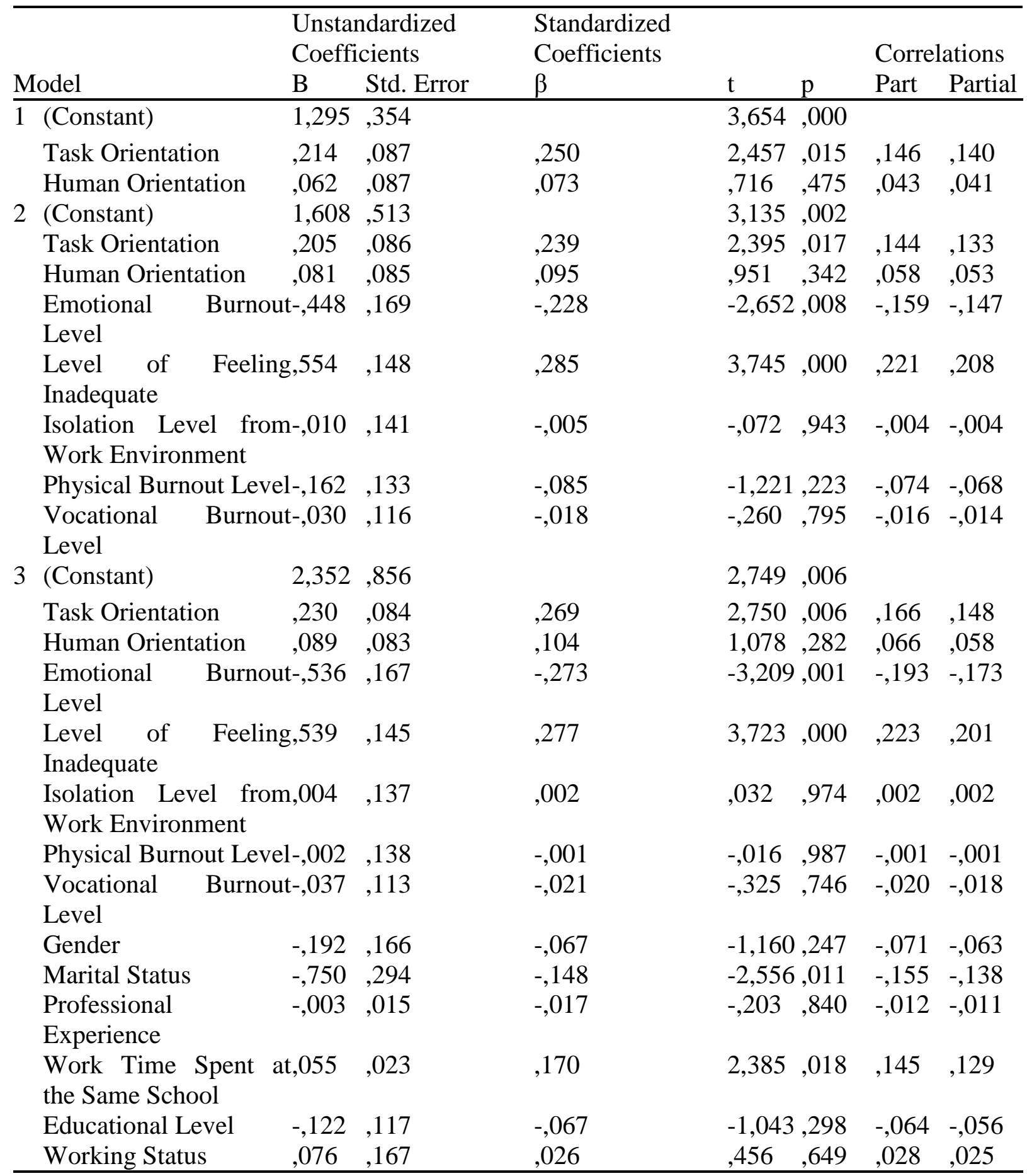


Table 5

\section{Coefficients $^{*}$}

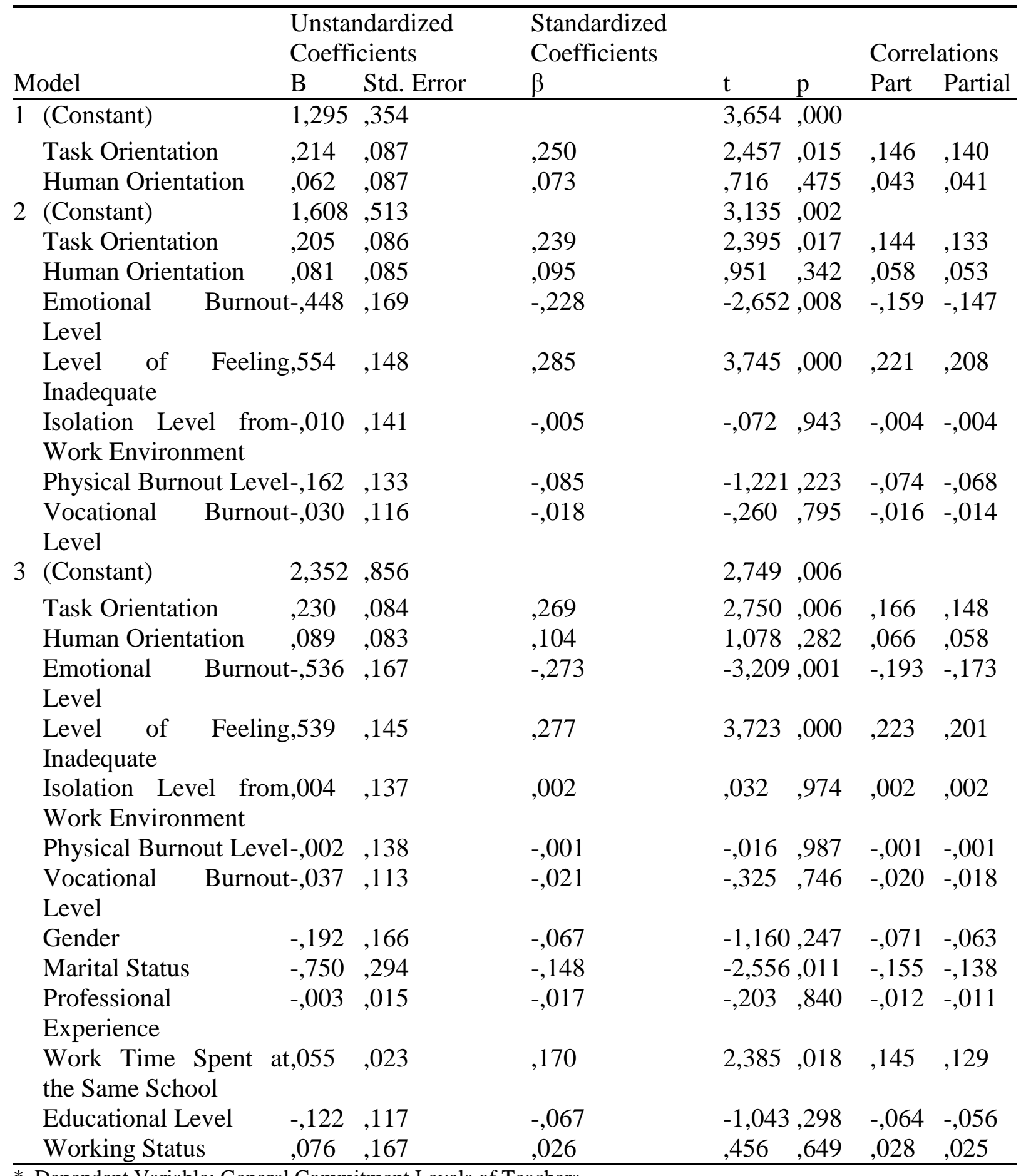

*. Dependent Variable: General Commitment Levels of Teachers.

When we analyzed findings in terms of all independent sub factors (Table 5); Task orientation levels of principals (B: .230, p: .006) from first block, emotional burnout levels (B: -,536, p: .001) and self-inadequate feelings levels (B: ,539, p: .000) of the teachers from 
second block, marital status (B: -,750, p: .011) and working time (B: ,055, p: .018) effects teacher commitment significantly.

Task orientation levels of principals, self-inadequate feelings levels of teachers, working time variables have positive effects on teacher commitment. Nonetheless, emotional burnout levels of teachers and marital status (coded as 1: married, 2: single) variables have negative effects on teacher commitment.

\section{Prediction on Normative Commitment Levels of Teachers}

Table 6

Hierarchical Regression Model for Normative Commitment Levels of Teachers.

\begin{tabular}{|c|c|c|c|c|c|c|c|c|c|}
\hline \multirow[b]{2}{*}{ Mode } & \multirow[b]{2}{*}{$\mathrm{R}$} & \multirow[b]{2}{*}{$\mathrm{R}^{2}$} & \multirow[b]{2}{*}{$\begin{array}{l}\text { Adjusted } \\
\mathrm{R}^{2}\end{array}$} & \multirow{2}{*}{$\begin{array}{l}\text { Std. } \\
\text { Error of } \\
\text { the }\end{array}$} & \multicolumn{5}{|c|}{ Change Statistics } \\
\hline & & & & & $\begin{array}{c}\mathrm{R}^{2} \\
\text { Change }\end{array}$ & $\begin{array}{c}\mathrm{F} \\
\text { Change }\end{array}$ & df & $\mathrm{df2}$ & $\begin{array}{c}\text { Sig. F Change } \\
\text { (p) }\end{array}$ \\
\hline 1 & $\underset{\mathrm{a}}{348}$ & $\begin{array}{c}, 12 \\
1\end{array}$ &, 115 & 1,45537 &, 121 & 19,052 & 2 & 277 &, 000 \\
\hline 2 & $\underset{\mathrm{b}}{429}$ & $\begin{array}{c}, 18 \\
4\end{array}$ & , 163 & 1,41524 & ,063 & 4,186 & 5 & 272 &, 001 \\
\hline 3 & $\begin{array}{c}486 \\
\mathrm{c}\end{array}$ & $\begin{array}{c}, 23 \\
6 \\
\end{array}$ & , 198 & 1,38480 &, 052 & 3,015 & 6 & 266 & ,007 \\
\hline $\begin{array}{l}\text { a. Pred } \\
\text { b. Prec } \\
\text { Inadeq } \\
\text { c. Pred } \\
\text { Inadeq } \\
\text { Experi }\end{array}$ & $\begin{array}{l}\text {, Is } \\
\text { rs: } \\
\text {, Is }\end{array}$ & 10 & $\begin{array}{l}\text { Task Orie } \\
\text { Task Orie } \\
\text { hysical Bur } \\
\text { Task Orie } \\
\text { hysical Bur } \\
\text { Spent at tl }\end{array}$ & $\begin{array}{l}\text { ntation, Hum } \\
\text { ntation, Hun } \\
\text { nout, Vocati } \\
\text { ntation, Hum } \\
\text { nout, Vocati } \\
\text { ne Same Sch }\end{array}$ & $\begin{array}{l}\text { in Orient } \\
\text { an Orient } \\
\text { nal Burn } \\
\text { in Orient } \\
\text { nal Burn } \\
\text { ol, Educa }\end{array}$ & $\begin{array}{l}\text { n } \\
\text { n, Emo } \\
\text { n, Emo } \\
\text { Gende } \\
\text { al Leve }\end{array}$ & & nou & $\begin{array}{l}\text { Feeling } \\
\text { Feeling } \\
\text {, Professional } \\
\text { us }\end{array}$ \\
\hline
\end{tabular}

As seen on Table 6, managerial style of the principal, teacher burnout and demographics explains $23.6 \%$ of variance on normative commitment levels of teachers. Variables in the first block, task orientation and human orientation explains $12.1 \%$ of the Total variance (R: .348, R2: .121, p: .000). When the second block added on, including emotional burnout level, level of feeling inadequate, isolation level from work environment, physical burnout level, vocational burnout level of the teachers, the model explains $18.4 \%$ of the variance on total and the level of prediction change is statistically significant (R: .429, R2: $.184, \mathrm{p}: .001)$. The effect of the second block on explained variance is $6.3 \%$. At the last model 
the single effect of variables in the third block, gender, marital status, professional experience, work time spent at the same school, educational level, working status, is $5.2 \%$ on prediction of normative commitment level and this effect changes explained variance significantly (R: .486, R2: .236, p: .007).

Table7

Coefficients*

$\begin{array}{ccc}\text { Unstandardized } & \text { Standardized } & \text { Correlation } \\ \text { Coefficients } & \text { Coefficients } & \mathrm{s}\end{array}$

Model

1 (Constant)

Task Orientation

Human Orientation

2 (Constant)

Task Orientation

Human Orientation

Emotional Burnout

Level

Level of Feeling

Inadequate

Isolation Level from

Work Environment

Physical Burnout Level

Vocational Burnout

Level

3 (Constant)

Task Orientation

Human Orientation

Emotional Burnout

Level

Level of Feeling

Inadequate

Isolation Level from

Work Environment

Physical Burnout Level

Vocational Burnout

Level

Gender

Marital Status

Professional Experience
B Std. Error

$1,110 \quad 380$

,236 ,093

, $099 \quad 093$

1,451 ,549

,228 ,092

,116 ,091

$-, 444 \quad, 181$

,608 , 158

,000 , 151

$-, 187$

, 142

$-, 075 \quad, 124$

2,222 ,924

,246 ,090

$, 127 \quad, 090$

$-, 512 \quad, 180$

$, 599 \quad, 156$

,006 , 148

$-, 042 \quad, 149$

$-, 074$

, 122

$-, 134 \quad, 179$

$-, 743$

, 317
$-, 004 \quad, 016$

$\beta$

,254

,107

,246

, 125

$-, 209$

,288

,000

$-, 090$

$-, 041$

,265

, 137

$-, 241$

, 284

,003

$-, 020$

$-, 040$

$-, 043$

$-, 135$ $\mathrm{t} \quad \mathrm{p}$ Part 1

2,924,004

143

060

2,641,009

2,492, 013 , 149

070

$\begin{array}{llll}-\quad 015 & - & -, 135\end{array}$

$2,456 \quad, 147$

210

-,003, 900 , 000,

$\begin{array}{llll}- & , 191 \quad-, 072\end{array}$

$1,311,079$

$\begin{array}{lll}-, 607,544 & - & -, 033\end{array}$

2,406, 017

146

1,419, 157, 087

$\begin{array}{llll}-\quad, 005 & - & -, 152\end{array}$

$2,843 \quad, 172$

3,834, 206

002 , 002, 969,

$\begin{array}{llll}-, 282,778 & - & -, 015\end{array}$

, 017

$\begin{array}{llll}-, 611,542 & - & -, 033\end{array}$

, 037

$\begin{array}{llll}-, 747,456 & - & -, 040\end{array}$

, 046

$\begin{array}{llll}- & , 020 \quad-\quad & -, 126\end{array}$

$\begin{array}{lllll}-, 022 & -, 268 & , 789 & - & -, 014\end{array}$ 


\begin{tabular}{lcccccccc}
$\begin{array}{l}\text { Work Time Spent at the } \\
\text { Same School }\end{array}$ &, 049 &, 025 &, 141 & 1,992 &, 047 &, 121 &, 107 \\
Educational Level &,- 168 &, 126 &,- 086 & - &, 184 & - &,- 071 \\
& & & & & 1,332 & &, 081 & \\
& & & & & & & \\
Working Status &, 194 &, 180 &, 061 & 1,078 &, 282 &, 066 &, 058 \\
\hline *. Dependent Variable: Normative Commitment Levels of Teachers.
\end{tabular}

Task orientation levels of principals (B: ,246, p: .007) from first block, emotional burnout levels (B: -,512, p: .005) and self-inadequate feelings levels (B: ,599, p: .000) of the teachers from second block, marital status (B: -,743, p: .020) and working time (B: ,049, p: .047) effects normative commitment significantly (Table 7).

Task orientation levels of principals, self-inadequate feelings levels of teachers, work time spent at the same school variables effects normative commitment positively. Emotional burnout levels of teachers and marital status variables have negative effects on normative commitment.

\section{Prediction on Continuance Commitment Levels of Teachers}

Table8

Hierarchical Regression Model for Continuance Commitment Levels of Teachers.

\begin{tabular}{|c|c|c|c|c|c|c|c|c|c|}
\hline \multirow[b]{2}{*}{ Model } & \multirow[b]{2}{*}{$\mathrm{R}$} & \multirow[b]{2}{*}{$\mathrm{R}^{2}$} & \multirow[b]{2}{*}{$\begin{array}{l}\text { Adjusted } \\
\mathrm{R}^{2}\end{array}$} & \multirow{2}{*}{$\begin{array}{c}\text { Std. } \\
\text { Error of } \\
\text { the } \\
\text { Estimate }\end{array}$} & \multicolumn{5}{|c|}{ Change Statistics } \\
\hline & & & & & $\begin{array}{c}\mathrm{R}^{2} \\
\text { Change }\end{array}$ & F Change & df1 & df2 & $\begin{array}{c}\text { Sig. F Change } \\
\text { (p) }\end{array}$ \\
\hline 1 &, $186^{\mathrm{a}}$ & 034 & ,028 & 1,44251 &, 034 & 4,946 & 2 & 277 & ,008 \\
\hline 2 &, $283^{\mathrm{b}}$ & ,080 &, 057 & 1,42078 & ,046 & 2,708 & 5 & 272 & 021 \\
\hline 3 &, $401^{\mathrm{c}}$ &, 161 &, 120 & 1,37230 & 081 & 4,259 & 6 & 266 &, 000 \\
\hline
\end{tabular}

According to the findings (Table 8), managerial style of the principal, teacher burnout and demographics explains $16.1 \%$ of variance on continuance commitment. Variables in the first block, task orientation and human orientation explain $3.4 \%$ of the Total variance (R: 
.186, R2: .034, p: .008). When the second block added on, including emotional burnout level, level of feeling inadequate, isolation level from work environment, physical burnout level, vocational burnout level of the teachers, the model explains $8 \%$ of the variance on total and the level of prediction change is statistically significant (R: .283, R2: .080, p: .021). The effect of the second block on explained variance is $4.6 \%$. At the last model the single effect of variables in the third block, gender, marital status, professional experience, working time, educational level, working status, is $8.1 \%$ on prediction of continuance commitment levels of teachers and this effect changes explained variance significantly (R: .401, R2: .161, p: .000).

Table 9

Coefficients*

\begin{tabular}{|c|c|c|c|c|c|c|c|}
\hline \multirow[b]{2}{*}{ Model } & \multicolumn{2}{|c|}{$\begin{array}{l}\text { Unstandardized } \\
\text { Coefficients }\end{array}$} & \multirow{3}{*}{$\begin{array}{c}\text { Standardized } \\
\text { Coefficients } \\
\beta\end{array}$} & \multirow{3}{*}{$\begin{array}{c}\mathrm{t} \\
4,390\end{array}$} & \multirow{3}{*}{$\begin{array}{c}\mathrm{p} \\
, 000\end{array}$} & \multicolumn{2}{|c|}{$\begin{array}{r}\text { Correlations } \\
\text { Partia }\end{array}$} \\
\hline & B & Std. Error & & & & Part & 1 \\
\hline 1 (Constant) & 1,652 & ,376 & & & & & \\
\hline Task Orientation & , 170 & ,093 & ,193 & 1,833 & ,068 & , 109 & 108 \\
\hline Human Orientation &,- 008 & ,093 &,- 009 &,- 085 & ,932 &,- 005 &,- 005 \\
\hline 2 (Constant) & 1,935 &, 551 & & 3,508 & ,001 & & \\
\hline Task Orientation & ,157 & ,092 & , 179 & 1,712 & ,088 & ,103 &, 100 \\
\hline Human Orientation &, 013 & ,092 & ,015 &, 141 &, 888 & ,009 & ,008 \\
\hline $\begin{array}{l}\text { Emotional Burnout } \\
\text { Level }\end{array}$ &,- 450 & , 182 &,- 224 & 2,478 & ,014 &,- 149 &,- 144 \\
\hline $\begin{array}{l}\text { Level of Feeling } \\
\text { Inadequate }\end{array}$ & ,445 & ,159 & ,223 & 2,795 & ,006 &, 167 &, 163 \\
\hline $\begin{array}{l}\text { Isolation Level from } \\
\text { Work Environment }\end{array}$ &,- 033 &, 152 &,- 016 &,- 219 & ,827 &,- 013 &,- 013 \\
\hline Physical Burnout Level &,- 116 &, 143 &,- 059 &,- 811 & ,418 &,- 049 &,- 047 \\
\hline $\begin{array}{l}\text { Vocational Burnout } \\
\text { Level }\end{array}$ & ,053 & ,124 & ,030 & ,429 & ,669 & ,026 & ,025 \\
\hline 3 (Constant) & 2,616 & ,915 & & 2,858 & ,005 & & \\
\hline Task Orientation & ,196 & ,090 & ,223 & 2,192 & ,029 & 133 &, 123 \\
\hline Human Orientation &, 017 & ,089 & 019 & , 186 & 853 & ,011 &, 010 \\
\hline $\begin{array}{l}\text { Emotional Burnout } \\
\text { Level }\end{array}$ &,- 576 & , 179 &,- 286 & 3, & ,001 &,- 194 &,- 181 \\
\hline $\begin{array}{l}\text { Level of Feeling } \\
\text { Inadequate }\end{array}$ & ,420 &, 155 & ,210 & 2,710 & ,007 &, 164 &, 152 \\
\hline $\begin{array}{l}\text { Isolation Level from } \\
\text { Work Environment }\end{array}$ &,- 004 &, 147 &,- 002 &,- 028 & ,977 &,- 002 &,- 002 \\
\hline Physical Burnout Level &, 076 &, 148 & ,038 &, 514 & ,608 &, 031 & ,029 \\
\hline $\begin{array}{l}\text { Vocational Burnout } \\
\text { Level }\end{array}$ &, 034 &, 121 & ,019 &, 283 &, 778 & ,017 & ,016 \\
\hline
\end{tabular}




\begin{tabular}{|c|c|c|c|c|c|c|c|}
\hline Gender &,- 329 &, 177 &,- 112 & $\begin{array}{c}- \\
1,857\end{array}$ &, 064 &,- 113 &,- 104 \\
\hline Marital Status &,- 727 & ,314 &,- 139 & 2,316 &, 021 &,- 141 &,- 130 \\
\hline $\begin{array}{l}\text { Professional } \\
\text { Experience }\end{array}$ &,- 002 & ,016 &,- 009 &,- 102 & ,918 &,- 006 &,- 006 \\
\hline $\begin{array}{l}\text { Work Time Spent at } \\
\text { the Same School }\end{array}$ &, 065 &, 024 & ,198 & 2,664 &, 008 &, 161 &, 150 \\
\hline Educational Level &,- 036 & ,125 &,- 020 &,- 292 &, 770 &,- 018 &,- 016 \\
\hline Working Status &,- 123 &, 178 &,- 041 &,- 691 &, 490 &,- 042 &,- 039 \\
\hline
\end{tabular}

Task orientation levels of principals (B:,196, p: .029) from first block, emotional burnout levels (B: -,576, p: .001) and self-inadequate feelings levels (B: ,420, p: .007) of the teachers from second block, marital status (B: -,727, p: .021) and work time spent at the same school (B: ,065, p: .008) effects continuance commitment significantly (Table 9).

Task orientation levels of principals, self-inadequate feelings levels of teachers, working time variables effects normative commitment positively. Emotional burnout levels of teachers and marital status variables have negative effects on continuance commitment.

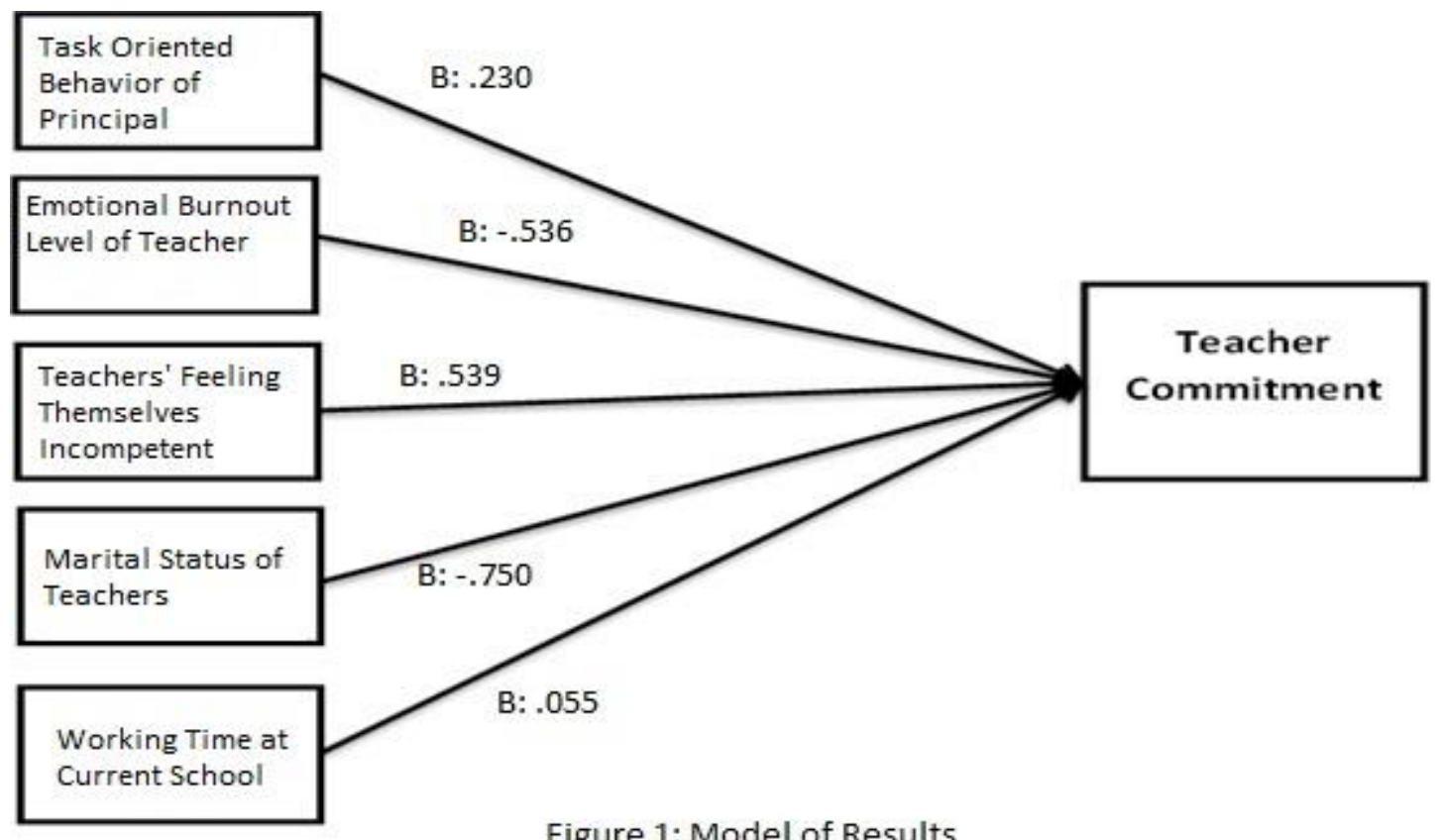

Figure 1: Model of Results 


\section{Discussions}

According to the findings, task orientation level of the principals, affects teacher commitment positively. Task orientation highlights protecting and sustaining rules and regulations about organizational structure (Blake \& Mouton, 1964). Besides, task orientation is known as initiating structure at the studies of Bass (1985), Stodgill (1974), Fiedler (1967)includes exact role definitions of superiors and subordinates. It is thought that clear role definitions, detailed guidelines and constancy on organizational aims protects teachers from organizational confusion and gives sense of confidence. Similarly, former researches state that, the degree of emphasis on rules, regulations and role definitions is an important predictor of employee commitment (Davenport, 2010; Dale \& Fox, 2008; Zeffane, 1994). This prediction spans on normative and continuance commitment levels too.

The negative effect of emotional burnout levels of teachers on general, normative and continuance commitment means that, emotionally exhausted teachers loses harmony with the organizational aims, incompatibility of values appears and teachers are losing desire to staying in organization. The research of Jung \& Kim (2012) supports the results for this evidence. According to Jung \& Kim, higher level of emotional exhaustion causes decreasing of commitment levels of subordinates.

Findings denotes that; self-inadequate feelings of teachers, predicts teacher general commitment level and sub factors. Although it sounds like a paradox that positive effect of self-inadequate feelings on teacher commitment can be thought as simple habituation to the work place and colleagues. Furthermore, if we think this case in sync with the other finding about positive effect of working time, collaborating for long times will create a family atmosphere and self-inadequate feelings might be lightened in this reliance ambiance and this relaxation may boost employee commitment. In addition, self-inadequate feelings may be creating fear of unemployment on teachers and this fear would be advancing effect on 
normative accordance and continuance commitment. There is a need of further research to support this thought.

Significant prediction capacity of marital status of teachers and working time variables on general, normative and especially on continuance commitment, shows that teachers in a routine of living at the same place and area for a long period accepting institutional goals and values, need stability and do not want to ruin their long period plans and they feel more flexible to be in harmony with institution and they intend to provide work continuity. Besides, being married is a factor increasing the coherence to institution and decreasing the attraction of professional mobility.

At the former researches, working time was used as an independent variable in a regression-based study and in a meta-analytic study (Borman\& Dowling, 2008; Dee, Henkin\& Singleton, 2006). But according to the findings of these studies, working time is not a significant predictor of teacher commitment. According to Kurşunoğlu, Bakay\&Tanriöğen (2010), working time during the school, and marital status effect teacher commitment. Findings of Kurşunoğlu, Bakay and Tanrı̈ğgen's study shows that married primary school teachers commitment levels are significantly higher than single teachers and working time increases teachers general, normative and continuance commitment levels.

\section{Conclusion}

Consequently, teachers have low-moderate burnout and commitment levels. Perceived task orientation level of the principal, emotional exhaustion level of the teacher, selfinadequate feelings of teacher, marital status and working time predicts teacher commitment statistically significant. We can also say at general and normative commitment, perceived task orientation level of the principal is the most effective predictor. But for continuance commitment, demographics like marital status and working time during the school are the 
most effective variables. Even though there is no significant difference between perceived task orientation and human orientation levels of the principals, human orientation does not have a marked prediction role on teacher commitment.

\section{References}

Allen, N. J., \& Meyer, J. P. (1990). The measurement and antecedents of affective, continuanceand normative commitment to the organization. Journal of Occupational Psychology, 63, pp. 1-18.

Bass, B. (1985). Leadership and performance beyond expectation. New York: Free Press.

Blake, R. R., \& Mouton, J. S. (1964). The managerial, grid. Houston, Texas: Gulf Publishing.

Borman, G. D., \& Dowling, N. M. (2008).Teacher attrition and retention: A meta-analytic and narrative review of the research. Review of Educational Research, 78(3) 376 409.doi: $10.3102 / 0034654308321455$.

Cherniss, C. (1980). Staff burnout: Job stress in the human services. Beverly Hills, CA: Sage

Dale, J. and Fox, M. (2008).Leadership style and organizational commitment: Mediating effect of role stress. Journal of Managerial Issues, 20(1), 1.09-130

Davenport, J. (2010). Leadership style and organizational commitment: the moderating effect of locus of control. ASBBS Annual Conference: Las Vegas.

Dee, J. R., Henkin, A. B., \& Singleton, C. A. (2006).Organizational commitment of teachers in urban schools: Examining the effects of team structures. Urban Education, 41(6), 603.doi: 10.1177/0042085906292512.

Ellett, F.S., \& Ericson, D.P. (1983).The logic of causal methods in social science. Synthese, 57, 67-82.doi: 10.1007/BF01064068

Fiedler, F. (1967). A theory of leadership effectiveness. New York: McGraw-Hill

Freudenberger, H.J. (1974). Staff burnout. Journal of Social Issue, 30, 159-165.

Hersey, P., \& Blanchard, K.H. (1988).Management and organizational behavior. Englewood Cliffs, New Jersey: Prentice-Hall. 
Jung, J., \& Kim, Y. (2012). Causes of newspaper firm employee burnoutin Korea and its impact on organizational commitment and turnover intention. The International Journal of Human Resource Management, 23(17), 3636-3651, doi:10.1080/09585192.2012.654806.

Kurşunoğlu, A., Bakay, E., \& Tanrıöğen, A. (2010).Organizational Commitment Levels of Elementary School Teachers. Pamukkale University Faculty of Education Journal, 28 (2), 101-115.

Maslach, C., \& Jackson, S.E., (1984). Burnout in organizational settings. Applied Social Psychology Annual, 5, 133-153.

Meyer, J. P., \& Allen, N. J. (1991). A three-component conceptualization of organizational commitment. Human Resource Management Review, 1, 61-89.

Miller, W.C. (1981). Staff morale, school climate and educational productivity. Educational Leadership, 38 (6), 483-486.

Modway, R., Steers, R., \& Porter, L. (1979). The measurement of organizational commitment. Journal of Vocational Behavior, 14, 224-227.

Northouse, P.G. (2004). Leadership: Theory and practice ( $3^{\text {rd }}$ ed.). Thousand Oaks, CA: Sage.

Nunnaly, J. C. (1978). Psychometric theory (2 ed.). New York: McGraw-Hill.

OECD (2010). PISA 2009 Results: What makes a school successful? - Resources, policies and practices (Volume IV), URL: http://dx.doi.org/10.1787/9789264091559-en.

Özdemir, N. (2008). To compare the exhausted levels of elementary school teachers who have learning disability students in their class rooms or not.(Master thesis, Published), Afyon Kocatepe University, Afyon.

Reddin, W.J. (1970). Managerial effectiveness. New York: McGraw-Hill.

Stodgill, R. (1974). Handbook of leadership: A survey of theory and research. New York: Free Press.

Warrick, D.D., (1981). Leadership styles and their consequences. Journal of Experimental Learning and Simulation, 3(4), 155-172. 
Y1ldirım, T. (2009). The influence of the primary education administrators personal and organizational worthy accommodation on the dedicating and estrangement. (Master thesis, Published), University of Uşak, Uşak.

Zeffane, R. (1994). Patterns of organizational commitment and perceived management style: a comparison of public and private-sector employees. Human Relations, 47(8), 9771010. 